\title{
Risk Factors for the Phytophthora-Induced Decline of Alder in Northeastern France
}

\author{
B. Thoirain, C. Husson, and B. Marçais
}

UMR 1136 Interactions Arbres/Microorganismes, INRA-Nancy, 54280 Champenoux, France. Accepted for publication 15 July 2006.

\begin{abstract}
Thoirain, B., Husson, C., and Marçais, B. 2007. Risk factors for the Phytophthora-induced decline of alder in northeastern France. Phytopathology 97:99-105.

A lethal disease of common alder caused by Phytophthora alni, a new hybrid pathogen, has been spreading in Europe since the early 1990s. In 2004, we conducted an epidemiological survey in northeastern France to determine disease frequency and to investigate the impact of environmental factors on disease prevalence. Seventy-eight plots in the RhinMeuse basin were investigated. The survey was structured to enable critical examination of the possible impact of nitrogen pollution of the river

differences existed between watercourse types. Lower proportions of diseased alders were found in watercourse types with rapid water flow, such as mountain streams of the Vosges and piedmont or watercourses on steep calcareous slopes, than in the slow watercourses of the low-lying valleys of the calcareous plateaus and of the clayey plains. Disease prevalence was not related to the total oxidized nitrogen concentration of the water. However, prevalence increased with the mean summer temperature of the river water and where clayey soils were found in the river banks. The results of this work can be used for the assessment of $P$. alni-induced alder decline risks in affected European countries and in areas where the disease could be introduced.
\end{abstract} water on disease prevalence. $P$. alni-induced alder decline was common throughout northeastern France. Altogether, disease was found in $80 \%$ of the plots containing alder, with $16 \%$ of all the alders affected. Striking
Additional keywords: Alnus glutinosa, riparian stands.
In northeastern France, the common alder (Alnus glutinosa) is often the main species present along watercourses, together with trees such as ash and willow. The alder has a pioneer role and is adapted to periodic flooding with the development of aerial adventitious roots on the trunk. The alder is able to consolidate and stabilize the river banks with its substantial deep root system. It also plays a role in water purification, absorbing phosphorus and some heavy metals like zinc and copper. Thus, this species is an important species for the riparian ecosystem. Alder ecology was recently reviewed by Claessens (5).

A new Phytophthora disease of alder was reported for the first time in 1993 in England (3,9). The causal pathogen was subsequently named Phytophthora alni (2) and has since been detected throughout most of Europe. A summary of the situation starting in 2000 , including a consensus description of the symptoms, was produced by Streito (18) as part of a European Concerted Action on the disease. The pathogen kills the bark at the base of the stem and in the roots. This bark-killing is often revealed externally by the production of tarry exudates. The leaves tend to be abnormally small, yellow, and sparse. Ultimately, trees show decline and may die.

In France, the disease was first reported in 1996 and is now present throughout the country (21). P. alni induces serious decline and mortality of alders: A survey conducted along the Moselle River in northeastern France in 2000 showed that approximately $20 \%$ of alders were diseased or dead (19). The disease impact is of the same order of magnitude in southern Britain (11). The disease was shown in Bavaria to have been largely introduced into the river system by planting infected material

Corresponding author: B. Marçais; E-mail address: marcais@ nancy.inra.fr

DOI: $10.1094 /$ PHYTO-97-0099

This article is in the public domain and not copyrightable. It may be freely reprinted with customary crediting of the source. The American Phytopathological Society, 2007 from nurseries (16). P. alni is considered an invasive pathogen in Europe. Molecular and cytological evidence indicates that $P$. alni is a hybrid species (1). Three subspecies have been described from European riparian ecosystems, with $P$. alni subsp. alni being the predominant species. Recent data show that the parent species of $P$. alni subsp. alni are $P$. alni subsp. uniformis and $P$. alni subsp. multiformis (12).

This disease is a major threat to the riparian ecosystem and causes problems for the management of the river banks. In order to manage the disease, we need extensive knowledge of its distribution in the river system and good understanding of the factors determining the disease risk. This type of data is also important for countries where the disease has not been introduced as it can help assess the threat this pathogen represents to alder ecosystems. While the distribution of the disease along the rivers of northeastern France has been documented (21), the environmental factors that influence disease risk remain poorly understood. In the United Kingdom, Gibbs et al. (11) found a correlation between nitrogen pollution and disease prevalence and it is important to determine whether this is a general relationship that holds for different areas of Europe. This epidemiological survey took place in northeastern France, on the Meuse, Moselle, and Sarre Rivers and their tributaries, in an area where the pathogen is well established (21). The aim of this research was to determine which factors are associated with high disease prevalence, with a particular focus on nitrogen pollution.

\section{MATERIALS AND METHODS}

Plot selection. To ensure proper information about water quality of the river, survey plots were chosen in the vicinity of water quality measurement stations maintained by the Agence de l'eau Rhin-Meuse. Using a watercourse GIS database provided by the Institut Géographique National (BD Carthage, IGN Paris 2004), we selected survey plots within sections of river about 1 to 
$3 \mathrm{~km}$ long, defined by the river managers and considered to be homogenous in terms of water characteristics. All the river sections that included a water quality measurement station were considered for sampling.

A preliminary survey on the Moselle River in $2000(19,22)$ suggested that the proportion of diseased trees was linked to several environmental factors, among which the most important were watercourse type (Table 1), riverbed morphology (curved or straight), and total oxidized nitrogen (TON) concentration of water. The classification of watercourses into types was done according to European Framework Directive 2000/60/EC in the field of EU water policy, and is used throughout Europe for river management purposes. The typology is based upon the morphology of the river (slope, width, water stream speed) and geology of the parental material. In an attempt to differentiate between these factors, we employed a stratified sampling scheme. Firstly, river sections were selected to provide a wide variety of watercourse types on as many different rivers as possible (Table 1). Secondly, sections with low/medium/high levels of TON were selected within each watercourse type: low $=0$ to $10 \mathrm{mg} \mathrm{liter}^{-1}$; medium $=10$ to $20 \mathrm{mg} \mathrm{liter}{ }^{-1} ;$ and high $=$ approximately $30 \mathrm{mg}$ liter $^{-1}$. Unfortunately, streams with a high level of TON did not exist in some of the watercourse types (T1, T2, T2b, and T3). Thirdly, and where possible, sample plots were selected on both curved and straight subsections of each riverbed section.

Infrared aerial photographs $(1: 25,000)$ provided by the Inventaire Forestier National (Nancy, France) were used to determine the presence of alder on the candidate river sections.

By stereoscopic examination of these photographs we were able to differentiate alders from willows and conifers (which have distinguishing crown structure and color) but not from ash or oak. This resulted in the exclusion of 25 sections of watercourse/TON type as being barren or just with willows/conifers, leaving 78 sections, located on 56 different rivers. At that time, potential survey plots on curved and straight parts of the river sections were identified: for the curved plots only the outside of the bend was used, and for the straight plots, just one of the banks. Up to six potential survey plots were selected in each section (one to three curved and one to three straight, depending upon what was available).

The water characteristics measured at those stations were downloaded from the website of the Agence de l'eau Rhin-Meuse (Banque de l'eau, Agence de l'eau Rhin-Meuse, Moulins-LèsMetz, France [provided by Agence de l'eau Rhin-Meuse]). The parameters used were water temperature, electrical conductivity,
$\mathrm{pH}$, biological oxygen demand, calcium, sodium, chloride, total oxidized nitrogen, orthophosphate, and ammonium concentrations. These were monitored routinely, with one measurement every 3 months for calcium, sodium, and chloride concentration, and one per month for all other parameters. Details on the measurement methods can be found on the Agence de l'eau Rhin-Meuse website. The parameter values used in the analysis were the means of all the measurements obtained from 1998 to 2003 (72 or 24 depending on the parameter) except for temperature. In order to estimate the river temperature during the growth season, only the six monthly values from May through October were used.

Survey procedure. The survey was conducted from June to July 2004. At each location, the first of the randomly designated survey plots was examined. If alders were lacking on the selected plot, the next randomly designated plot was surveyed. The survey unit was a maiden (a tree that has never been logged) or a coppice (a tree with several stems arising from past logging) A. glutinosa over $1.3 \mathrm{~m}$ high and within $2 \mathrm{~m}$ of the river bank. Trees were surveyed on a bank length of $100 \mathrm{~m}$ or until 30 alders were encountered. If less than 15 alders were present on the $100 \mathrm{~m}$, additional trees up to a total of 15 to 20 were selected on a further length of bank, providing that the plot remained homogeneous.

For each alder, we counted the number of stems above $2 \mathrm{~cm}$ diameter at breast height (dbh) and measured the three biggest stems at this height. We recorded the presence of cankers or tarry spots on the lower bole and the decline status of the crown. The rating scale for crown symptoms was as follows: $0=$ healthy; $1=$ small dead branches at the periphery of the upper part of the crown, less than $50 \%$ of the crown affected; $2=$ sparse crown with small yellow leaves and/or dead large limbs in the upper part of the crown, more than $50 \%$ of the crown affected; and $3=$ dead. Additionally, we recorded the total number of alder stems above 5 $\mathrm{cm}$ dbh per $100 \mathrm{~m}$ for each plot. We also recorded the watercourse width (measured with a telemeter); the presence of bridges, of paths, or of roads parallel to the riverbed; soil texture of the river bank (clay loam, loam, sandy loam, or loamy sand, determined by visual and tactile comparison with soil of known texture); and the percentage of tree cover on the river bank by classes: 0 to $20 \%$, 20 to $40 \%, 40$ to $60 \%, 60$ to $80 \%$, and 80 to $100 \%$ (all trees, whatever the species, were within $2 \mathrm{~m}$ of the river).

One to three symptomatic alders were sampled in each plot in order to verify the presence of $P$. alni, depending on availability of cankered trees. Pieces of the necrotic bark lesion were excised, wrapped in a plastic bag with water, and transported to the

TABLE 1 . Watercourse types in the Rhin-Meuse basin investigated in this study

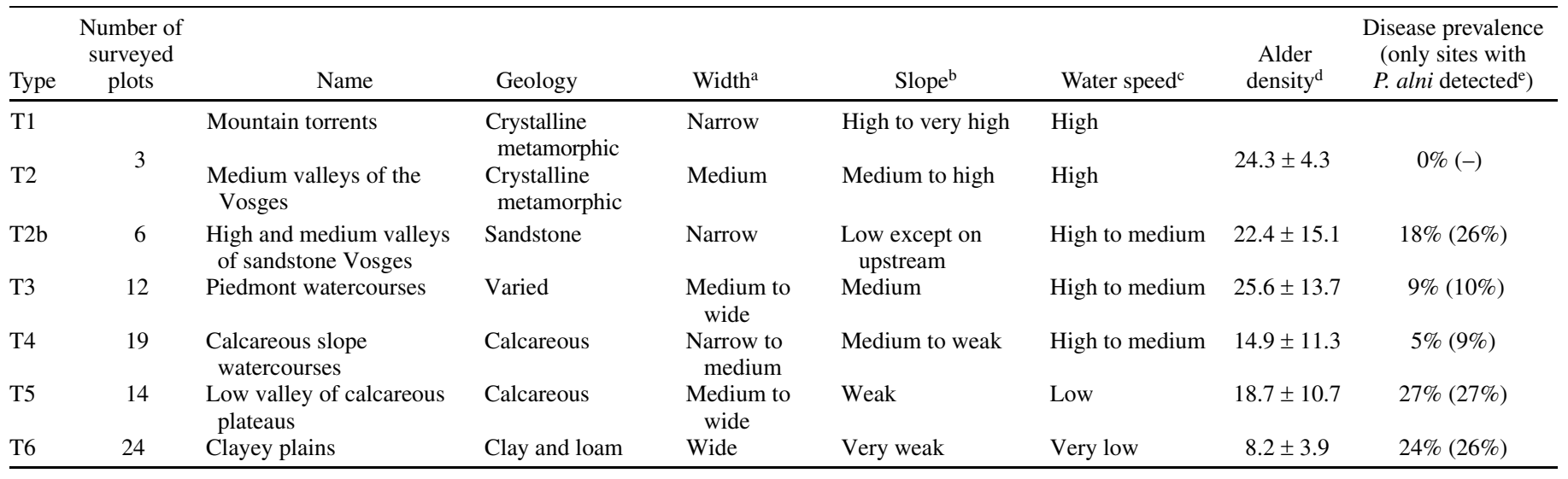

a Narrow, 0 to $15 \mathrm{~m}$; medium, 15 to $50 \mathrm{~m}$; wide, above $50 \mathrm{~m}$.

b Weak slope, 0 to $5 \%$; medium slope, 5 to $10 \%$; high slope, above $10 \%$.

${ }^{\mathrm{c}}$ Low, 1 to $10 \mathrm{~cm} \mathrm{~s}^{-1}$; medium, 10 to $30 \mathrm{~cm} \mathrm{~s}^{-1}$; high, 30 to $70 \mathrm{~cm} \mathrm{~s}^{-1}$.

${ }^{\mathrm{d}}$ Based on the count of stems above $5 \mathrm{~cm}$ dbh on $100 \mathrm{~m}$ river bank using all the plots visited, even those with too few alder for inclusion in the survey or with no trees seen on aerial photographs.

e Site where $P$. alni was detected on at least one tree by isolation or polymerase chain reaction. 
laboratory for analysis. Each sample was separated into two subsamples, one for direct isolation on Phytophthora-specific culture medium (corn meal agar with antibiotics, [20]), and the other for molecular detection using the sequence characterized amplified regions method developed by Ioos et al. (13). A second sampling was done during the summer of 2005 on trees at the sites where $P$. alni detection had not been successful in 2004.

Treatment of data. The prevalence of the disease, calculated as the proportion of alders with cankers or tarry spots and/or crown symptom class of 2 or more, was analyzed by logistic regression, using the procedure GENMOD of SAS (SAS/STAT 8.1, SAS Institute, Cary, NC). This type of analysis assumes that the response variable-disease prevalence-follows a binomial distribution and that a function of the response (the link function) is linearly related to the independent variables (6). We used as link function the Logit function. In logistic regression, the mostused model-building procedure is a forward type selection of the independent variables (6). Firstly, the effect of the factors measured at the tree level, such as dbh, were evaluated. Then the data were grouped by plot and the effects of environmental factors were studied, testing in the regression model the effect of each individual factor taken separately. We used the following model: $\log \left[P_{r} /\left(1-P_{r}\right)\right]=\alpha+\beta \times \mathrm{RF}_{r}$, with $P_{r}$ the likelihood for trees to be diseased and $\mathrm{RF}_{r}$ the examined risk factor.

In a third step, we examined which factors remained significantly linked to disease prevalence when the effect of watercourse type was taken into account. Watercourses T1, T2, and T3 were combined because of low numbers. We fitted models such as: $\log \left[P_{r} /\left(1-P_{r}\right)\right]=\alpha+\beta \times \mathrm{WT}+\gamma \times \mathrm{RF}_{r}$, with WT being the watercourse type. Finally, models best explaining the prevalence of the disease were sought, including as possible independent variables all those that had shown a significant link with prevalence and using a forward type selection. We computed the odds ratio as the exponential of model parameters (6). Odds ratios are estimates of the increase in risk for an alder of being diseased for each unit of the independent parameter. Odds ratio confidence limits were computed according to the Wald test.

\section{RESULTS}

Prevalence of disease. In total, 97 sections of river were visited in the search for survey plots. Alders were present in large enough numbers for inclusion in the survey in 58 sections, of which 20 contained both the curved and straight morphologies, 33 had only the straight morphology, and 5 had only the curved morphology. Alders were abundant on all the watercourse types except type T6 (Table 1). Also, a large portion of the Meuse River lacked alder. Altogether, the survey included 78 plots located on 35 different rivers.

Symptoms attributed to $P$. alni were recorded in $77.6 \%$ of the sections, scattered over the entire survey area (Fig. 1). Overall, $16 \%$ of the alders were recorded as being diseased, either having tarry spots on the trunk or crown symptoms with a rating of at least 2. Bark samples were taken from 59 survey plots and $P$. alni was confirmed by either isolation or polymerase chain reaction (PCR) on at least one tree in 54 of them $(92 \%)$. The few affected plots where $P$. alni was not confirmed by isolation or PCR had very few symptomatic trees, and in particular, few or no cankered

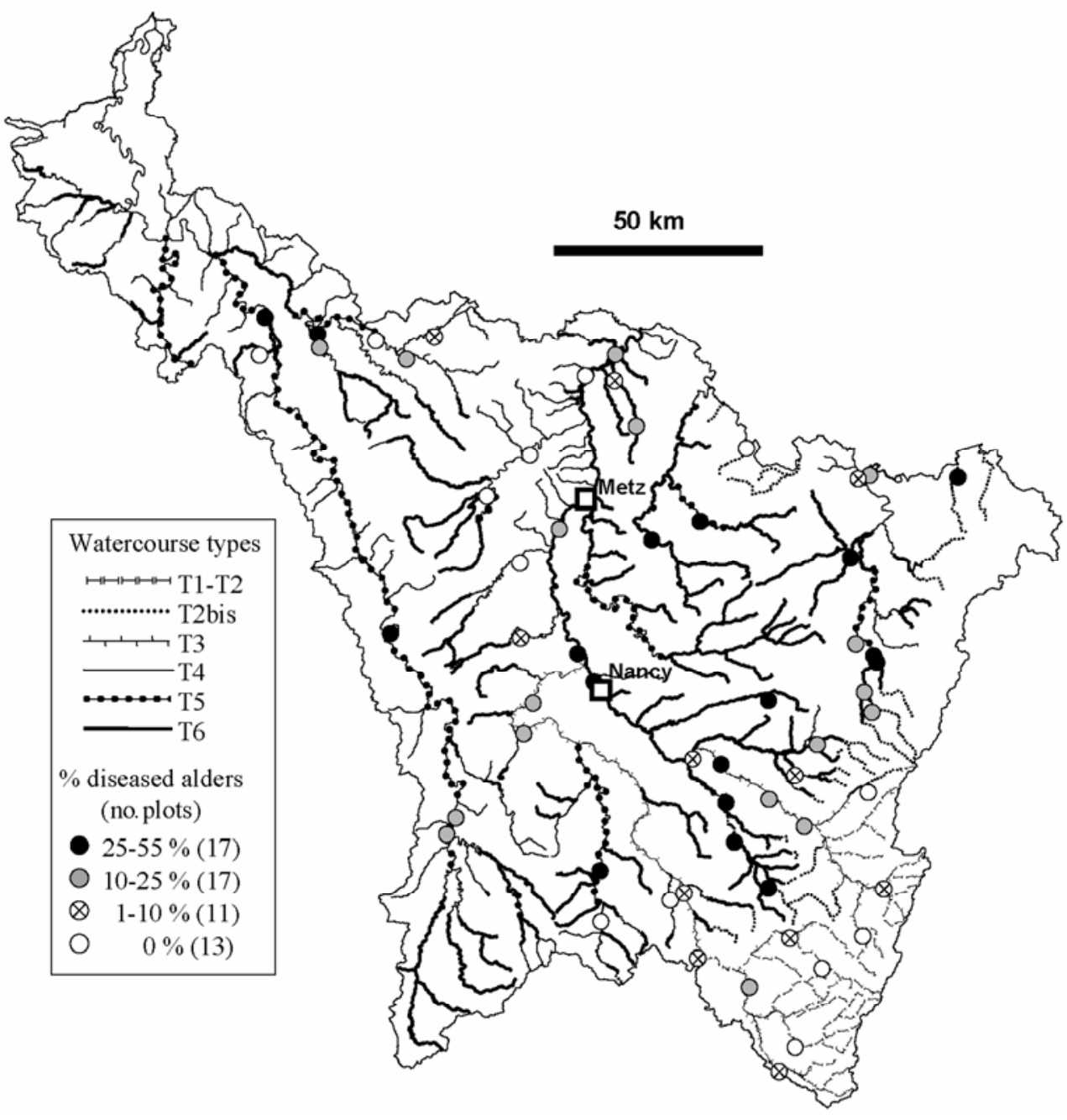

Fig. 1. Distribution of the watercourse types and Phytophthora alni prevalence in riparian stands of northeastern France. 
trees, making testing very difficult. Altogether, the pathogen was confirmed on $42 \%$ of the trees sampled on the 59 plots $(11 \%$ by isolation alone, $14 \%$ by PCR alone, and $17 \%$ by both techniques).

Factors affecting disease risk. No significant association was found between the prevalence of disease and the factors measured at the tree level (such as dbh), so all further analysis was done at the plot level. No significant difference was found between the two riverbed morphologies (curve, 16\% diseased alders; straight, $18.2 \%$ diseased alders; $\chi^{2}=0.61, P$ value $=0.435$ ) and further analysis showed that ignoring these factors did not introduce a bias in the analysis.

The range of values encountered for the different water parameters is reported in Table 2. Among the tested environmental factors, some, such as biological oxygen demand, TON, $\mathrm{NH}_{4}^{+}$, and orthophosphate concentration in water were clearly not associated with disease prevalence (Table 3). Other parameters showed a significant association. Thus, watercourse types T2b, T5, and T6 were much more affected than T1, T2, T3, and T4 (Fig. 1, Table 2). A nested model with only two groups of watercourse types, T1-T2-T3-T4 and T2b-T5-T6, was not significantly different from the model including all five groups $\left(\chi^{2}\right.$ $=2.87, P$ value $=0.412$ ), indicating that no loss of information was induced by this grouping.

River sections with banks characterized by loamy clay showed more disease than those with other types of soil (Fig. 2, Table 3). Prevalence of the disease increased with mean summer water temperature (Fig. 3) and decreased with the riparian tree cover of the bank. Wide rivers were significantly more diseased than narrow ones (Table 2). Finally, increased electrical conductivity was positively related to disease prevalence (Table 3). An important contribution to conductivity was made by the chloride concentration, which in one area was enhanced by the presence of a salt-laden geological layer. An increasing level of chloride was significantly linked to an increase in disease (Table 3). Finally, disease prevalence increased when the plot was in the vicinity of a bridge crossing the river (Table 3 ).

Table 4 shows the results obtained with models that included both the watercourse type and one of the other explanatory variables. This analysis enables determination of which factors are important in explaining the intra-type variability in disease prevalence. Some environmental factors such as soil texture, water temperature, vegetative cover, and presence of a nearby bridge crossing the river explained part of this intra-type variability in disease prevalence, while the other factors that were examined did not. Limiting the analysis to only the 54 plots where $P$. alni had been detected by PCR or isolation did not change the results (Table 4). In particular, the difference in disease prevalence between the watercourse types did not change (Table 1).

Finally, two multivariate models explaining disease prevalence were fitted using a forward selection procedure. Both included watercourse type, water temperature, and tree cover on the bank, but one included soil texture while the other included the presence/absence of a bridge in the plot vicinity (Table 5). The two models showed some over dispersion as evidenced by the deviance/degrees of freedom (df) of about 1.8 (one would expect a value of 1 ).

The factor that most increased disease risk was the watercourse type, with an odds ratio of 3.4. This can be interpreted as a 3.4fold increase in the probability of an alder located on a T2b, T5, or T6 watercourse to be infected by $P$. alni compared with one located on a T1, T2, T3, or T4 watercourse. In comparative terms, the texture of soil and the presence of a bridge on the river were less important. Finally, there was a 1.2-fold increase in the disease risk with every $1{ }^{\circ} \mathrm{C}$ increase in water temperature and a 0.9 -fold decrease with every $10 \%$ increase in the tree cover. It should be pointed out that this relationship between tree cover and $P$. alni prevalence was not linked to a reduction in the alder cover due to disease, as the tree cover on the bank and the alder density per $100 \mathrm{~m}$ were not significantly correlated (Spearman $\mathrm{r}$ of $0.095, P$ value $=0.409$ ).

\section{DISCUSSION}

As $P$. alni is an invasive pathogen actively spreading through European watercourses, the disease prevalence at any one location may be expected to be strongly influenced by its position within the river system. New infections are created when the pathogen is introduced into previously uncontaminated watercourses via the planting of infected nursery-raised alders or via contaminated soil

TABLE 3. Results of the logistic regression models ${ }^{\mathrm{a}}$ relating single environmental factors to the prevalence of Phytophthora alni on riparian alders in northeastern France

\begin{tabular}{lccr}
\hline Factor & Df & $\chi^{2}$ & $P$ value \\
\hline Tree cover & 4 & 22.24 & $<0.001$ \\
Watercourse width & 1 & 10.45 & 0.001 \\
Soil texture & 3 & 22.67 & $<0.001$ \\
Presence of road or bridge ${ }^{\mathrm{b}}$ & 2 & 12.47 & 0.002 \\
Watercourse type $_{\text {Summer water temperature }}^{\quad(M a y-O c t o b e r)}$ & 4 & 79.88 & $<0.001$ \\
$\quad$ Water pH & 1 & 25.70 & $<0.001$ \\
DBO & & & \\
Total oxidized nitrogen & 1 & 3.49 & 0.062 \\
NH ${ }_{4}^{+}$ & 1 & 0.63 & 0.428 \\
Orthophosphate & 1 & 0.65 & 0.428 \\
Conductivity & 1 & 0.03 & 0.874 \\
Calcium & 1 & 0.166 & 0.684 \\
Chloride & 1 & 8.427 & 0.004 \\
& 1 & 5.62 & 0.018 \\
\end{tabular}

a Models are of the form $\log \left[P_{i} /\left(1-P_{i}\right)\right]=\alpha+\beta \times \mathrm{RF}_{i}$, with $P_{i}$ the likelihood for trees to be diseased and $\mathrm{RF}_{i}$ the examined risk factor.

b The three classes are no road or bridge in the vicinity, a road parallel to the river, and a road or railway crossing the river on a bridge.

${ }^{c} \mathrm{DBO}_{5}$ represents the biological demand in oxygen in 5 days.

TABLE 2. Range values of the tested environmental factors

\begin{tabular}{|c|c|c|c|}
\hline Environmental factors & $\begin{array}{l}\text { All the sites } \\
\text { ( } 78 \text { plots) }\end{array}$ & $\begin{array}{c}\text { Sites with Phytophthora alni } \\
\text { detected }^{\mathrm{a}} \text { (56 plots) }\end{array}$ & $\begin{array}{l}\text { Sites with } P \text {. alni not detected } \\
\text { (22 plots) }\end{array}$ \\
\hline Watercourse width (m) & $18.7(3-53)$ & $22.4(4-53)$ & $9.2(3-23)$ \\
\hline Summer water temperature $\left({ }^{\circ} \mathrm{C}\right)$ & $15.4(11.6-19.7)$ & $15.6(12.8-19.7)$ & $14.8(11.6-17.4)$ \\
\hline Water $\mathrm{pH}(\mathrm{pH})$ & $7.5(6.8-8.1)$ & $7.5(6.8-8.1)$ & $7.7(6.9-8.1)$ \\
\hline $\mathrm{DBO}_{5}{ }^{\mathrm{b}}\left(\mathrm{mg} \mathrm{liter}^{-1}\right)$ & $2.7(2.0-4.1)$ & $2.7(2.0-3.9)$ & $2.8(2.0-4.1)$ \\
\hline Total oxidized nitrogen $\left(\mathrm{mg}\right.$ liter $\left.^{-1}\right)$ & $9.1(2.4-21.0)$ & $8.5(2.8-19.0)$ & $11.0(2.4-21.0)$ \\
\hline $\mathrm{NH}_{4}^{+}\left(\mathrm{mg}\right.$ liter $\left.{ }^{-1}\right)$ & $0.2(0.1-1.5)$ & $0.2(0.1-0.9)$ & $0.3(0.1-1.5)$ \\
\hline Orthophosphate $\left(\mathrm{mg} \mathrm{liter}^{-1}\right)$ & $0.3(0.1-1.1)$ & $0.2(0.1-0.9)$ & $0.3(0.1-1.1)$ \\
\hline Conductivity $\left(\mu \mathrm{S} \mathrm{cm}^{-1}\right)$ & $561(67-2,925)$ & $511(69-2,925)$ & $688(67-1,842)$ \\
\hline Calcium (mg liter $\left.{ }^{-1}\right)$ & $77(4-333)$ & $66(5-320)$ & $106(4-333)$ \\
\hline Chloride (mg liter $\left.{ }^{-1}\right)$ & $47(3-870)$ & $51(4-870)$ & $38(3-488)$ \\
\hline
\end{tabular}

a Site where $P$. alni was detected on at least one tree by isolation or polymerase chain reaction.

${ }^{\mathrm{b}}$ DBO5 represents the biological demand in oxygen in 5 days. 
moved on wheels or the feet of people or animals $(14,16)$. The disease then spreads (presumably mainly via zoospores) downstream from the infection focus $(14,16)$. Introduction is less likely in more remote places such as the Vosges mountains, and hence disease occurrence is likely to be lower along small streams than along the main watercourses. This could be a significant source of confusion in this study, and indeed, the prevalence of disease increased with river width. However, this bias should not strongly affect the results of our study for several reasons: (i) the disease is widespread in the Rhin-Meuse area and is known to have occurred for several years upstream from at least one-third of the study plots where no affected trees were recorded (21); (ii) some of the small streams of the upper parts of the river systems are seriously affected by the disease (type T2b); (iii) the width of the rivers was not among the variables selected for the multivariate models; and (iv) analysis of the data after having removed the plots with no diseased alders did not change the conclusions. In particular, the estimate of disease prevalence in the different watercourse types was not affected if only plots with disease present were taken into account. Nevertheless, it remains possible that the disease has been introduced more recently in remote places and in small river sections, affecting our prevalence estimate.

The overall disease prevalence was quite high, with the value per plot ranging from $5 \%$ to approximately $25 \%$, depending upon the watercourse types. These values are comparable to those reported for the Moselle River alone by Streito et al. (19) and to those reported by Gibbs et al. (10) for rivers in southern Britain. The frequency of confirmation of $P$. alni from symptomatic trees (42\%) might appear low. However, this pathogen has repeatedly been reported as difficult to isolate (20); therefore a low detection rate is not unexpected. Although molecular detection is very useful in many cases, in particular with older infections, it is not efficient enough to be used alone.

The stratified sampling scheme that we used enabled us to draw some clear conclusions. We did not find a relationship between the level of oxidized nitrogen and disease prevalence and thus cannot confirm the observations of Gibbs et al. (11), made in southern Britain, that high levels of oxidized nitrogen are associated with high $P$. alni prevalence. The association they

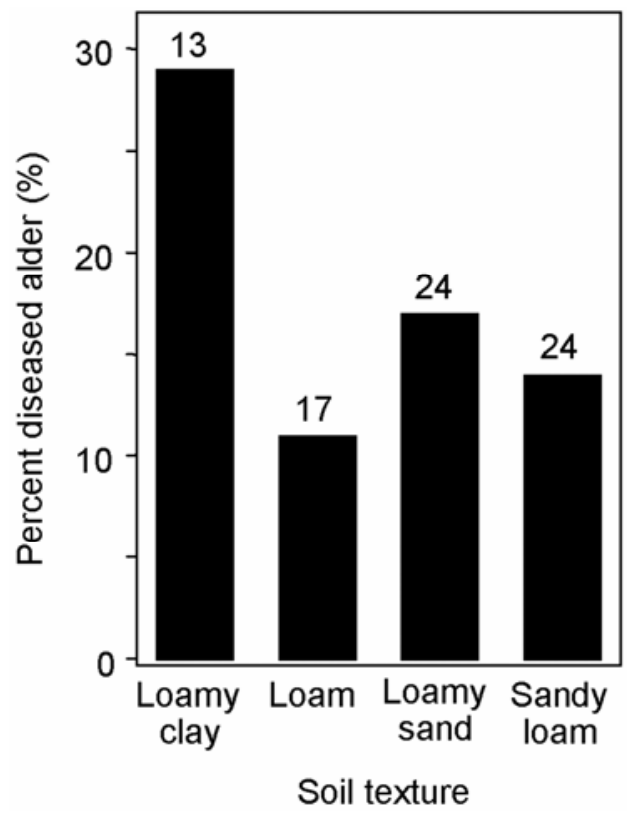

Fig. 2. Prevalence of Phytophthora alni on common alder in northeastern France and texture of river bank soil. Diseased trees were considered those with tarry spots and/or crown symptom rating of at least 2 . The numbers of surveyed plots appear above the bars. found was probably related to the fact that their high-nitrate rivers had a greater exposure to human activity than their low-nitrate ones, and hence were more likely to be exposed to disease introduction, a possibility pointed out in the discussion section of their paper. We experienced a similar problem during our preliminary survey $(19,22)$. However, it should be noted that we had a larger range of TON concentration than in the Gibbs et al. (11) study (2 to $21 \mathrm{mg} \mathrm{liter}^{-1}$ compared with 0 to $10 \mathrm{mg} \mathrm{liter}^{-1}$ ) which might in part explain the difference. Nor did any of the other parameters related to the chemical content of the water (like water conductivity, and calcium and chloride concentrations) show a strong relationship to disease risk when examined within plots of the same watercourse type. Thus, the correlations shown in Table 2 may well be spurious. However, the relation between chloride concentration and $P$. alni prevalence merits further investigation, because another study shows similar links for Citrus infected by $P$. citrophthora $(7,8)$. In that case, an increase of chloride level in irrigation water exacerbates $P$. citrophthora infection.

In contrast, other factors appear to be strongly related to disease prevalence. An increase in the temperature of the river water was positively linked to the prevalence. This could be explained by the fact that optimal growth temperature of the pathogen is at 22.5 to $25^{\circ} \mathrm{C}$ (3). Sporulation of $P$. alni is very poor at 9 to $10^{\circ} \mathrm{C}$ (4). This relationship is interesting when considered in relation to the evolution of the disease in Great Britain during the last decade. While the disease was more severe in 1994 in the Midlands and in Wales than in southern England, this situation is now reversed, with a more rapid rate of disease increase in the south (10). This might represent a response to higher water temperatures in southern England rivers.

The disease risk is higher in soil with a fine texture, in particular, in clay loams. This is often described in the literature for Phytophthora diseases $(15,17)$. The relationship between the tree cover and disease prevalence is difficult to interpret. This result is not caused by a decrease in tree cover on severely affected sites due to alder death, as alder density and tree cover were not correlated. It might be related to an indirect effect on water temperature, shading decreasing the water temperature in the vicinity of the bank.

Altogether, the most important risk factor found was the watercourse type to which the river section belonged. The rivers

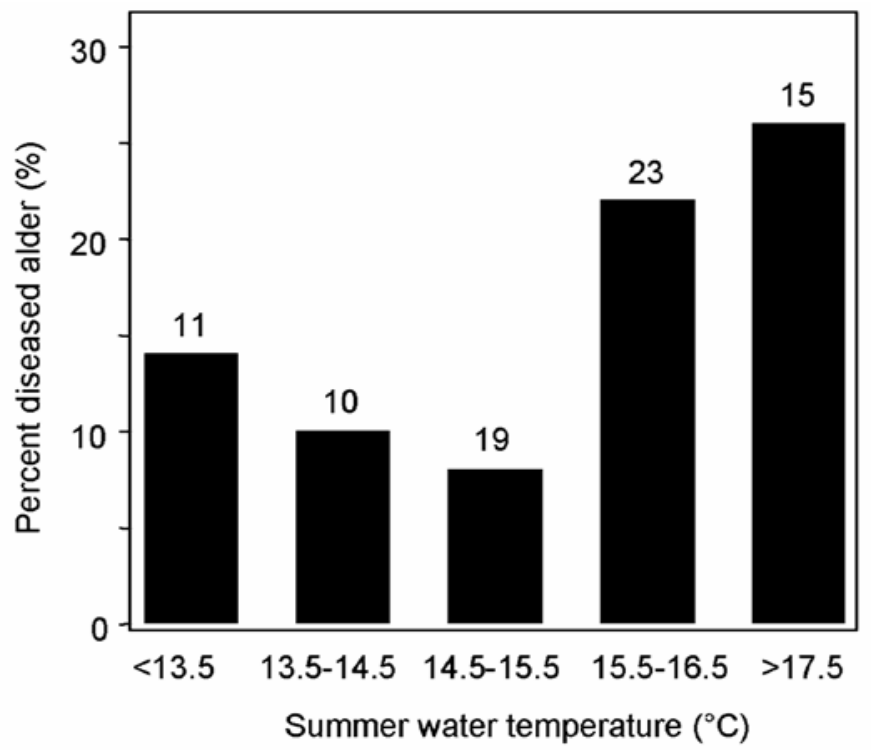

Fig. 3. Relationship between summer water temperature (May to October) and Phytophthora alni prevalence in northeastern France. Diseased trees are those with tarry spots and/or crown symptom of at least 2 . The numbers of surveyed plots appear above the bars. 
could be separated into two groups: T1, T2, T3, and T4 types; and $\mathrm{T} 2 \mathrm{~b}$, T5, and T6 types. The evolution of alder decline was reported to show very high heterogeneity among infected plots of northeastern France (10), with dramatic deterioration of the riparian stands in some cases while in others, the prevalence did not increase in 5 years. It is especially interesting to note that the plots that did not deteriorate belonged to T3 watercourses, while those that did deteriorate belonged to T6 watercourses. The watercourse typology incorporates many different environmental factors and it is thus difficult to pinpoint the factor(s) that may be responsible for this large difference in disease prevalence. It is clearly not related to any of the factors that we included in the analysis. However, examining the properties of the different watercourse types, it would appear that one difference between those two groups might be the speed of the water flow. Thus, the low prevalence group comprises watercourses where the water flows fast, while the high prevalence group comprises watercourses where water flow is generally slow. Slowly moving water might favor $P$. alni by resulting in a high level of zoospore inoculum at the tree base.

The idea that slow-moving water favors the disease is supported by other observations. Streito et al. (19) observed a high prevalence of disease on the banks of lakes compared with the nearby banks of the Moselle River. Similarly, Gibbs et al. (10), in reviewing the situation in the United Kingdom, commented that serious disease often occurred on sites from which flood water was slow to drain away. It might also be an underlying reason for the higher prevalence of disease that we found in the vicinity of bridges, as these often exacerbate the flooding that occurs upstream at times of high river flow. Such an association between bridges crossing the river and high $P$. alni infection of riparian alder was also mentioned by Jung and
Blaschke (16). We attempted to separate riparian plots according to the morphology of the rivers-straight or curved-with the underlying idea that this might influence disease development through changes in the speed of the water flow. The preliminary survey indicated that this micro-site characteristic might be important for disease prevalence $(19,22)$ but we found no confirmatory evidence.

Although we found several factors that showed a statistically significant association with frequency of $P$. alni trees, the fitted multivariate models poorly explained the disease prevalence as shown by the significant overdispersion reflected in the high deviance/df ratio. This is usually explained by either the lack of an important risk factor in the model or the presence of an aggregated pattern of the disease. In our case, large residuals were often associated with high disease risk plots but no symptomatic trees. One possible explanation is that the disease had just not yet been introduced to those sites.

It will be possible, using the results of this study, to draw maps of alder decline risk for the rivers of the Rhin-Meuse basin. The knowledge of risk associated with individual watercourse types will be of great help to the river managers. Significant parts of the river system of northeastern France appear to be at a low disease risk, in particular many rivers of the Vosges mountains and of the Piedmont that show high populations of alders. By contrast, the rivers of the plain are often at a high risk. This is a particular problem for rivers of type T6 that often show very low tree cover. The lack of riparian trees is one of the causes of river eutrophication, and river managers are starting a program of tree planting, including alders, on the banks of those rivers. The planting of alder, apart from the possible introduction of new infection foci due to infected seedlings, clearly poses a problem because of the high disease risk. The results presented here also

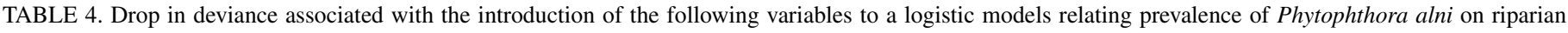
alders to the watercourse type ${ }^{a}$

\begin{tabular}{|c|c|c|c|}
\hline \multirow[b]{2}{*}{ Factor } & \multirow[b]{2}{*}{ Df } & \multicolumn{2}{|c|}{$\chi^{2}(P$ value $)$} \\
\hline & & All sites & Sites with $P$. alni detected ${ }^{\mathrm{b}}$ \\
\hline Tree cover & 4 & $10.33(0.035)$ & $6.03(0.197)$ \\
\hline Watercourse width & 1 & $6.42(0.011)$ & $1.02(0.313)$ \\
\hline Soil texture & 3 & $7.27(0.064)$ & $8.63(0.035)$ \\
\hline Presence of road or bridge $\mathrm{e}^{\mathrm{c}}$ & 2 & $5.48(0.065)$ & $6.63(0.010)$ \\
\hline Summer water temperature (May-October) & 1 & $9.75(0.002)$ & $5.37(0.021)$ \\
\hline Water $\mathrm{pH}$ & 1 & $0.20(0.654)$ & $4.34(0.037)$ \\
\hline $\mathrm{DBO}_{5}{ }^{\mathrm{d}}$ & 1 & $0.11(0.745)$ & $3.38(0.086)$ \\
\hline Total oxidized nitrogen & 1 & $1.00(0.317)$ & $2.77(0.096)$ \\
\hline $\mathrm{NH}_{4}^{+}$ & 1 & $0.74(0.390)$ & $0.97(0.325)$ \\
\hline Orthophosphate & 1 & $0.02(0.889)$ & $0.82(0.366)$ \\
\hline Conductivity & 1 & $0.35(0.555)$ & $3.04(0.081)$ \\
\hline Calcium & 1 & $0.01(0.933)$ & $1.07(0.301)$ \\
\hline Chloride & 1 & $2.03(0.154)$ & $0.02(0.899)$ \\
\hline
\end{tabular}

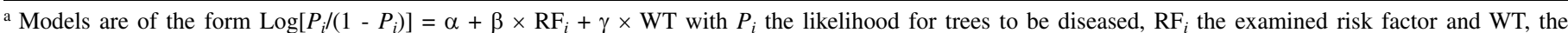
watercourse type and are compared with the model $\log \left[P_{i} /\left(1-P_{i}\right)\right]=\alpha+\gamma \times$ WT.

b Site where $P$. alni was detected on at least one tree by isolation or polymerase chain reaction.

c The three classes are no road or bridge in the vicinity, a road parallel to the river, and a road or railway crossing the river on a bridge.

${ }^{\mathrm{d}} \mathrm{DBO}_{5}$ represents the biological demand in oxygen in 5 days.

TABLE 5. Odds ratio associated with the two fitted multivariate models ${ }^{\mathrm{a}}$

\begin{tabular}{|c|c|c|}
\hline Factor & Odds ratio (confidence limits) & $P$ value \\
\hline \multicolumn{3}{|l|}{ Model 1: Deviance/df $=1.82$} \\
\hline Soil texture: $\mathrm{Cl}$ versus L-Ls-Sl & $1.7(1.1-2.5)$ & 0.046 \\
\hline Watercourse type: T2b-5-6 versus T1-2-3-4 & $3.6(2.4-5.3)$ & $<0.001$ \\
\hline Summer temperature & $1.2(1.1-1.3)$ & 0.007 \\
\hline Tree cover (per $10 \%$ cover) & $0.89(0.83-0.95)$ & 0.022 \\
\hline \multicolumn{3}{|l|}{ Model 2: Deviance/df $=1.75$} \\
\hline Presence of a bridge on the river & $1.9(1.3-2.7)$ & 0.008 \\
\hline Watercourse type: T2b-5-6 versus T1-2-3-4 & $3.4(2.2-5.2)$ & $<0.001$ \\
\hline Summer temperature & $1.2(1.1-1.3)$ & 0.007 \\
\hline Tree cover (per $10 \%$ cover) & $0.89(0.83-0.95)$ & 0.015 \\
\hline
\end{tabular}

a Model 1 and 2 were fitted with scale factors of deviance/df value. 
give some basis for risk assessment in other European countries or in areas such as the United States where the disease has not been introduced.

\section{ACKNOWLEDGMENTS}

We thank O. Caël and B. Bertin for assistance with the survey and M. Goteghebeur, from the Agence de l'eau du bassin Rhin-Meuse, who guided the study of river characteristics. C. Cluzeau, from the Inventaire Forestier National, allowed us to use the aerial photographs to check for alder presence. We thank J. Gibbs and E. Hansen, who reviewed the manuscript and provided useful comments. This study was funded by the Agence de l'eau du bassin Rhin-Meuse.

\section{LITERATURE CITED}

1. Brasier, C. M., Cooke, D. E., and Duncan, J. M. 1999. Origin of a new Phytophthora pathogen through interspecific hybridization. Proc. Natl. Acad. Sci. USA 96:5878-5883.

2. Brasier, C. M., Kirk, S. A., Delcan, J., Cooke, D. E., Jung, T., and Man In't Veld, W. A. 2004. Phytophthora alni sp. Nov. and its variants: Designation of emerging heteroploid hybrid pathogens spreading on Alnus trees. Mycol. Res. 108:1172-1184.

3. Brasier, C. M., Rose, J., and Gibbs, J. N. 1995. An unusual Phytophthora associated with widespread alder mortality in Britain. Plant Pathol. 44:999-1007.

4. Chandelier, A., Laurent, F., Abras, S., Debruxelles, N., and Cavelier, M. 2004. Phytophthora disease of alder: Role of bacteria in the production of sporangia. Third Int. IUFRO Meeting on Phytophthora in Forest and Natural Ecosystems. IUFRO, Vienna.

5. Claessens, H. 2003. The alder population in Europe. Pages 5-14 in: Phytophthora Disease of Alder in Europe. J. N. Gibbs, C. van Dijk, and J. Webber, eds. For. Res. Bull. 126.

6. Collett, D. 1991. Modelling Binary Data. Chapman \& Hall, NY.

7. El-Guilli, M., Benyahia, H., Jrifi, A., and Besri, M. 2000. Effet de la salinité de l'eau d'irrigation sur de la gommose du tronc d'agrumes due à Phytophthora citrophthora. Fruits (Paris) 55:181-186.

8. El-Guilli, M., Besri, M., Ibriz, M., and Farith, A. 2001. Effet de la salinité sur la croissance et l'agressivité in vitro de Phytophthora citrophthora. Al Awamia 103:51-60.

9. Gibbs, J. N. 1995. Phytophthora root disease of alder in Britain. Pages
661-664 in: EPPO Bull. 25.

10. Gibbs, J. N., Cech, T., Jung, T., and Streito, J. C. 2003. Field studies on dissemination of the alder Phytophthora and disease development. Pages 55-64 in: Phytophthora Disease of Alder in Europe. J. N. Gibbs, C. van Dijk, and J. Webber, eds. For. Res. Bull. 126.

11. Gibbs, J. N., Lipscombe, M. A., and Peace, A. J. 1999. The impact of Phytophthora disease on riparian populations of common alder (Alnus glutinosa) in southern Britain. Eur. J. For. Pathol. 29:39-50.

12. Ioos, R., Andrieux, A., Marçais, B., and Frey, P. 2006. Genetic characterization of the natural hybrid species Phytophthora alni as inferred from nuclear and mitochondrial DNA analyses. Fungal Genet. Biol. 43:511-529.

13. Ioos, R., Husson, C., Andrieux, A., and Frey, P. 2005. SCAR-based PCR primers to detect the hybrid Phytophthora causing alder disease in Europe. Eur. J. Plant Pathol. 112:323-335.

14. Jules, E. S., Kauffman, M. J., Ritts, W. D., and Carroll, A. L. 2002. Spread of an invasive pathogen over a variable landscape: A nonnative root rot on Port Orford cedar. Ecology 83:3167-3181.

15. Jung, T., Blaschke, H., and Oswald, W. 2000. Involvement of soilborne Phytophthora species in Central European oak decline and effect of site factors on the disease. Plant Pathol. 49:706-718.

16. Jung, T., and Blaschke, M. 2004. Phytophthora root and collar rot of alders in Bavaria: Distribution, modes of spread, and possible management strategies. Plant Pathol. 53:197-208.

17. Lévy, A. 1995. L'encre du chêne rouge d'Amérique: Répartition en France, facteurs stationnels dans le Piémont des Pyrénées occidentales. Cah. DSF. No. 1. Minist. Agric. Pèche, Paris.

18. Streito, J. C. 2003. Phytophthora disease of alder: Identification and distribution. Pages 25-38 in: Phytophthora disease of Alder in Europe. J. N. Gibbs, C. van Dijk, and J. Webber, eds. For. Res. Bull. 126.

19. Streito, J. C., Alioua, M., and Marçais, B. 2001. The impact of Phytophthora disease on riparian population of common alder (Alnus glutinosa) along the Moselle River (NE France). Second Int. IUFRO Meeting on Phytophthora in Forest and Natural Ecosystems. IUFRO, Vienna.

20. Streito, J. C., Jarnouen de Villartay, G., and Tabary, F. 2002. Methodsfor isolating the alder Phytophthora. For. Pathol. 32:193-196.

21. Streito, J. C., Legrand, P., Tabary, F., and Jarnouen de Villartay, G. 2002. Phytophthora disease of alder (Alnus glutinosa) in France: investigation between 1995 and 1999. For. Pathol. 32:179-191.

22. Thoirain, B. 2004. Etude épidémiologique du dépérissement des aulnes glutineux (Alnus glutinosa) dû à Phytophthora alni. DAA de l'ENSAIA, Nancy, France. 